\title{
Effects of soil temperature and moisture on methane uptake and nitrous oxide emissions across three different ecosystem types
}

\author{
G. J. Luo ${ }^{1}$, R. Kiese ${ }^{1}$, B. Wolf ${ }^{1, *}$, and K. Butterbach-Bahl ${ }^{1}$ \\ ${ }^{1}$ Institute for Meteorology and Climate Research, Karlsruhe Institute of Technology, Garmisch-Partenkirchen, Germany \\ *current address: EMPA, Dübendorf, Switzerland
}

Correspondence to: K. Butterbach-Bahl (klaus.butterbach-bahl@ kit.edu)

Received: 14 December 2012 - Published in Biogeosciences Discuss.: 22 January 2013

Revised: 18 April 2013 - Accepted: 19 April 2013 - Published: 13 May 2013

\begin{abstract}
In this paper, we investigate similarities of effects of soil environmental drivers on year-round daily soil fluxes of nitrous oxide and methane for three distinct semi-natural or natural ecosystems: temperate spruce forest, Germany; tropical rain forest, Queensland, Australia; and ungrazed semi-arid steppe, Inner Mongolia, China. Annual cumulative fluxes of nitrous oxide and methane varied markedly among ecosystems, with nitrous oxide fluxes being highest for the tropical forest site (tropical forest: $0.96 \mathrm{~kg} \mathrm{Nha}^{-1} \mathrm{yr}^{-1}$; temperate forest: $0.67 \mathrm{~kg} \mathrm{Nha}^{-1} \mathrm{yr}^{-1}$; steppe: $0.22 \mathrm{~kg} \mathrm{Nha}^{-1} \mathrm{yr}^{-1}$ ), while rates of soil methane uptake were approximately equal for the temperate forest $\left(-3.45 \mathrm{~kg} \mathrm{Cha}^{-1} \mathrm{yr}^{-1}\right)$ and the steppe $\left(-3.39 \mathrm{~kg} \mathrm{Cha}^{-1} \mathrm{yr}^{-1}\right)$, but lower for the tropical forest site $\left(-2.38 \mathrm{~kg} \mathrm{Cha}^{-1} \mathrm{yr}^{-1}\right)$.

In order to allow for cross-site comparison of effects of changes in soil moisture and soil temperature on fluxes of methane and nitrous oxide, we used a normalization approach. Data analysis with normalized data revealed that, across sites, optimum rates of methane uptake are found at environmental conditions representing approximately average site environmental conditions. This might have rather important implications for understanding effects of climate change on soil methane uptake potential, since any shift in environmental conditions is likely to result in a reduction of soil methane uptake ability. For nitrous oxide, our analysis revealed expected patterns: highest nitrous oxide emissions under moist and warm conditions and large nitrous oxide fluxes if soils are exposed to freeze-thawing effects at sufficiently high soil moisture contents. However, the explanatory power of relationships of soil moisture or soil temperature to nitrous oxide fluxes remained rather poor $\left(R^{2} \leq 0.36\right)$.
\end{abstract}

When combined effects of changes in soil moisture and soil temperature were considered, the explanatory power of our empirical relationships with regard to temporal variations in nitrous oxide fluxes were at maximum about $50 \%$. This indicates that other controlling factors such as $\mathrm{N}$ and $\mathrm{C}$ availability or microbial community dynamics might exert a significant control on the temporal dynamic of nitrous oxide fluxes. Though underlying microbial processes such as nitrification and denitrification are sensitive to changes in the environmental regulating factors, important regulating factors like moisture and temperature seem to have both synergistic and antagonistic effects on the status of other regulating factors. Thus we cannot expect a simple relationship between them and the pattern in the rate of emissions, associated with denitrification or nitrification in the soils.

In conclusion, we hypothesize that our approach of data generalization may prove beneficial for the development of environmental response models, which can be used across sites, and which are needed to help achieve a better understanding of climate change feedbacks on biospheric sinks or sources of nitrous oxide and methane.

\section{Introduction}

Nitrous oxide and methane are two of the most important radiative trace gases in the atmosphere. Since the industrial revolution, the concentration of these greenhouse gases have increased from 270 to $319 \mathrm{ppbv}$, and from 0.72 to 1.77 ppmv, contributing at present approximately 5 and $12 \%$, respectively, to observed global warming (Solomon et al., 2007). Soils of natural and semi-natural terrestrial ecosys- 
tems, such as grasslands and forests, are major global sources and sinks/sources of nitrous oxide and methane and thus play an important role in regulating atmospheric concentration of these gases. However, soil-atmosphere exchange of methane and nitrous oxide varies considerably across different terrestrial ecosystem types such as steppe, temperate, and tropical forests (e.g. Breuer et al., 2000; Brumme and Borken, 1999; Dutaur and Verchot, 2007; Pilegaard et al., 2006; Schaufler et al., 2010; Smith et al., 2000; Stehfest and Bouwman, 2006). Differences in plant and soil microbial communities, soil chemistry and physics, management, soil acidification, and atmospheric nitrogen deposition are drivers for site variation in methane and nitrous oxide fluxes. Furthermore, seasonal variability of fluxes is likely to be controlled by soil temperature and moisture and their effects on substrate availability, soil aeration, gas diffusivity, and thus on microbial processes such as mineralization, nitrification, denitrification, methane oxidation, and methanogenesis.

Methane and nitrous oxide are both produced (or consumed) as a result of microbial processes in the soil (Conrad, 1996). In soils, methane can be formed under anaerobic conditions by methanogens. Under aerobic conditions, both methane that has been produced in anaerobic parts of the soil and atmospheric methane diffusing into the topsoil can be oxidized by methanotrophs (Le Mer and Roger, 2001). Nitrous oxide is naturally produced in soils by microbial processes of nitrification and denitrification (Bleakley and Tiedje, 1982; Bowden, 1986).

Soil temperature and water content directly affect production and consumption of these greenhouse gases through their effects on metabolic activity of microorganisms and plants, soil aeration, substrate availability, and redistribution. Effective gas diffusivity, which increases with increased airfilled porosity, controls the exchange of gases between the atmosphere and soil and affects soil aeration. This process indirectly controls the capacity of the soil to produce or consume nitrous oxide and methane. In soils from different ecosystems, moisture and temperature have been identified as key controls on nitrous oxide and methane trace gas production and consumption by many field investigations. Studies in temperate forest (Butterbach-Bahl and Papen, 2002; Castro et al., 1994, 1995; Peterjohn et al., 1994; Wu et al., 2010a) and temperate grassland (Chen et al., 2010; van den Pol-van Dasselaar et al., 1998; Wu et al., 2010b) have revealed strong temporal patterns in nitrous oxide and methane fluxes corresponding closely with seasonal changes in moisture and temperature. Reports on $\mathrm{C}$ and $\mathrm{N}$ trace gas exchange between tropical rain forest soils and the atmosphere are still limited. However, results from previous experiments at different tropical rain forest sites (Breuer et al., 2000; Butterbach-Bahl et al., 2004; Kiese et al., 2003; Seiler et al., 1984; Teh et al., 2008; Teh and Silver, 2006; Werner et al., 2007a; Yan et al., 2008; Yashiro et al., 2008) indicate that the seasonality of fluxes of methane and nitrous oxide are mainly driven by changes in these two environmental parameters as well.
However, to our knowledge there is no study available that comprehensively compares responses of $\mathrm{C}$ - and $\mathrm{N}$-trace gas fluxes to changes in temperature and soil moisture across different ecosystem types. The study by Groffman et al. (2000) only evaluates nitrous oxide fluxes across ecosystems at the annual scale, thereby finding that coherent patterns in annual nitrous oxide fluxes at the ecosystem scale in forest, cropland, and rangeland ecosystems exist, but these patterns vary by regions and only emerge with continuous (in a resolution of at least daily) flux measurements over multiple years.

All three investigated ecosystems in this study (temperate forest, semi-arid steppe, and tropical forest) are among the dominating ecosystem types on earth. For instance, emissions of nitrous oxide from tropical rain forest soils are thought to contribute approximately $20 \%$ to the global atmospheric budget of this primary climate-relevant trace gas (Solomon et al., 2007). Assuming that the observed variability of nitrous oxide and methane fluxes at our observation sites may be representative for their ecosystem types and the respective climatic regime, a cross-site comparison of fluxes may help to identify overarching patterns of soil moisture and temperature effects on soil greenhouse gas (GHG) emissions. Specific objectives addressed in this study were (1) to evaluate seasonal variations and event based patterns of methane and nitrous oxide fluxes in three different ecosystem types, (2) to relate temporal changes of GHG fluxes to changes in temperature and moisture for the given ecosystem, and (3) to investigate overarching patterns in GHG fluxes as a response to changes in soil moisture and temperature across the three ecosystem types.

\section{Materials and methods}

\subsection{Study sites}

In this study, a cross-site comparison of soil nitrous oxide and methane fluxes, soil temperature, and soil moisture was conducted for three different ecosystems: spruce forest, temperate climate; ungrazed steppe, semi-arid climate; and tropical rain forest, wet tropical climate (with pronounced dry and wet seasons). The main characteristics of the sites are given in Table 1.

Data for temperate forest was obtained from continuous measurements at the Höglwald Forest, a well-studied spruce plantation site in southern Germany, which receives high rates of atmospheric $\mathrm{N}$ deposition $\left(20-30 \mathrm{~kg} \mathrm{~N} \mathrm{ha}^{-1} \mathrm{yr}^{-1}\right.$ ) (Luo et al., 2012). Continuous measurements of soil methane and nitrous oxide fluxes were started in November 1993 and were continued since then. For cross-site analysis, we used observational data of the years 1995 and 1997, since these years are typical years with regard to flux magnitudes, seasonal flux patterns, and environmental conditions (Luo et al., 2012). We did not use average values across all observation years, since averaging would have dampened the observed 
Table 1. Main characteristics of the different measuring sites.

\begin{tabular}{|c|c|c|c|}
\hline & Höglwald, Germany ${ }^{\mathrm{a}}$ & Bellenden Ker, Austalia ${ }^{\mathrm{b}}$ & UG99, Inner Mongolia, China ${ }^{c}$ \\
\hline Location & $\begin{array}{l}11^{\circ} 11^{\prime} \mathrm{E} \\
48^{\circ} 30^{\prime} \mathrm{N}\end{array}$ & $\begin{array}{l}145^{\circ} 54^{\prime} \mathrm{E} \\
17^{\circ} 16^{\prime} \mathrm{S}\end{array}$ & $\begin{array}{l}116^{\circ} 40^{\prime} \mathrm{E} \\
43^{\circ} 33^{\prime} \mathrm{N}\end{array}$ \\
\hline $\begin{array}{l}\text { Climate (Köppen-Geiger } \\
\text { climate classification) }^{\mathrm{d}}\end{array}$ & $\begin{array}{l}\text { Temperate oceanic } \\
\text { climate }^{\mathrm{Dfb}}\end{array}$ & $\begin{array}{l}\text { Tropical rainforest } \\
\text { climate }^{\mathrm{Af}}\end{array}$ & $\begin{array}{l}\text { Temperate semi-arid } \\
\text { climate }^{\text {Dwb }}\end{array}$ \\
\hline $\begin{array}{l}\text { Height above } \\
\text { sea level }(\mathrm{m})\end{array}$ & 540 & 80 & 1268 \\
\hline $\begin{array}{l}\text { Annual precipitation } \\
(\mathrm{mm})\end{array}$ & $\begin{array}{l}997(1995) \\
627(1997)\end{array}$ & $\begin{array}{l}2678 \\
(\text { Nov 2001-Oct 2002) }\end{array}$ & $\begin{array}{l}356 \\
\text { (15 Aug 2007-14 Aug 2008) }\end{array}$ \\
\hline $\begin{array}{l}\text { Annual temperature } \\
\left({ }^{\circ} \mathrm{C}\right)\end{array}$ & $\begin{array}{l}7.9(1995) \\
9.4(1997)\end{array}$ & $\begin{array}{l}23.8 \\
(\text { Nov 2001-Oct 2002) }\end{array}$ & $\begin{array}{l}2.1 \\
(15 \text { Aug 2007-14 Aug 2008) }\end{array}$ \\
\hline Vegetation type & Picea abies & $\begin{array}{l}\text { Complex mesophyll } \\
\text { vine forest }\end{array}$ & Leymus chinensis \\
\hline Slope $\left(^{\circ}\right)$ & - & $9.0-12.0$ & $2.2-2.7$ \\
\hline $\begin{array}{l}\text { Soil parent } \\
\text { material }\end{array}$ & $\begin{array}{l}\text { Pleistocene loess over } \\
\text { tertiary sand deposits }\end{array}$ & Granite & Loess \\
\hline \multicolumn{4}{|c|}{ Soil parameters $(0-10 \mathrm{~cm}$ mineral soil $)$} \\
\hline Soil type & Typic Hapludalf & Ustochrept & Calcic Chernozem \\
\hline $\mathrm{pH} \pm \mathrm{SE}$ & 3.59 & $4.1 \pm 0.03^{\mathrm{f}}$ & $6.8 \pm 0.27^{\mathrm{f}}$ \\
\hline $\begin{array}{l}\text { Bulk density } \\
\left(\mathrm{g} \mathrm{cm}^{-3}\right) \pm \mathrm{SE}\end{array}$ & $1.033 \pm 0.05$ & $1.09 \pm 0.03$ & $1.09 \pm 0.12$ \\
\hline $\mathrm{C}: \mathrm{N}$ ratio & 19 & 12.1 & $9.7 \pm 0.7^{\mathrm{e}}$ \\
\hline Organic $\mathrm{C}$ content $(\%)$ & 1.91 & 3.11 & $2.55 \pm 0.63$ \\
\hline \multicolumn{4}{|l|}{ Soil texture $(\%)^{\mathrm{d}}$} \\
\hline Sand & $50-64$ & 57 & 48.3 \\
\hline Silt & $30-38$ & 21 & 25.8 \\
\hline Clay & $5-11$ & 22 & 25.9 \\
\hline
\end{tabular}

${ }^{a}$ Kreutzer (1995); Rothe et al. (2002); Butterbach-Bahl et al. (2002); Luo et al. (2012).

${ }^{\mathrm{b}}$ Kiese und Butterbach-Bahl (2002).

c Compiled from data from Chen et al. (2010) and Liu et al. (2007).

${ }^{d}$ Peel et al. (2007).

e $0-4 \mathrm{~cm}$ soil depth.

${ }^{\mathrm{f}}$ Kiese et al. (2003).

"-" not determined.

Dfb Warm summer (dry winter) climate.

Af Tropical rainforest climate.

Dwb Warm summer climate (with dry season).

response of microbial processes involved in soil-atmosphere $\mathrm{CH}_{4}$ and $\mathrm{N}_{2} \mathrm{O}$ exchange to changes in soil temperature and moisture. High soil-thawing nitrous oxide fluxes occur occasionally at the Höglwald site (approximately every third year, Luo et al., 2012). In order to consider such irregular events in our cross-site data analysis, we randomly chose $365 \mathrm{ob}-$ servation days from the years 1995 and 1997 to form a new, more representative dataset for this site. For the specific site analysis (e.g. Table 2), all data obtained in both years were considered, whereas for cross site comparison a synthetic dataset was derived by randomly selecting $50 \%$ of data for the year 1995 and $50 \%$ of data from the year 1997. Daily precipitation and air temperature at $2 \mathrm{~m}$ above ground level for 1995 and 1997 were obtained from the German Weather Service station Augsburg-Mühlhausen, which is about $20 \mathrm{~km}$ northwest from the Höglwald Forest site. Soil temperature at $5 \mathrm{~cm}$ soil depth was measured every minute by PT100 probes (IMKO GmbH, Germany) in close vicinity to the chambers (Values at $10 \mathrm{~cm}$ are not available across the entire observation period.). Hourly soil moisture measurements were carried out with horizontally installed TDR probes (IMKO $\mathrm{GmbH}$, Germany, or UMS, Germany) at $10 \mathrm{~cm}$ soil depth. Due to instrumental failure and removal of the soil moisture sensors, in situ soil moisture measurements were not available for 1997. To fill this gap, a machine-learning technique, known as support vector machine (SVM), was employed (for details see Luo et al., 2012). 
Table 2. Flux rates of nitrous oxide and methane from soils of each land use type as observed for all temperature and moisture conditions. Annual cumulative values are summed after linear interpolation. All parameters are significantly $(p<0.05)$ different between sites.

\begin{tabular}{lcccc}
\hline Land use types & Höglwald (1997) & Höglwald (1995) & Rain forest & Steppe \\
\hline $\begin{array}{l}\text { Mean soil temperature } \\
\left({ }^{\circ} \mathrm{C}\right)\end{array}$ & $6.9 \pm 0.2$ & $7.2 \pm 0.3$ & $22.33 \pm 0.2$ & $4.95 \pm 0.6$ \\
$\begin{array}{l}\text { Mean volumetric water } \\
\text { content (vol \%) }\end{array}$ & $29.1 \pm 0.2$ & $33.0 \pm 0.2$ & $22.09 \pm 0.5$ & $13.51 \pm 0.5$ \\
$\begin{array}{l}\text { Annual methane uptake } \\
\left(\mathrm{kg} \mathrm{CH}_{4}-\mathrm{Cha}^{-1} \mathrm{yr}^{-1}\right)\end{array}$ & -3.45 & -2.79 & -2.38 & -3.39 \\
$\begin{array}{l}\text { Annual nitrous oxide emission } \\
\left(\mathrm{kg} \mathrm{N}_{2} \mathrm{O}-\mathrm{N} \mathrm{ha}^{-1} \mathrm{yr}^{-1}\right)\end{array}$ & 0.67 & 0.82 & 0.96 & 0.22 \\
\hline
\end{tabular}

Nitrous oxide and methane fluxes of the tropical rain forest site were obtained at a site in the coastal lowlands of the "Wet Tropics", Queensland, Australia, approximately $70 \mathrm{~km}$ south of Cairns. Plant biodiversity is relatively high with over 130 plant species including 63 different kinds of trees occurring in a defined plot of $20 \mathrm{~m}$ by $50 \mathrm{~m}$, and thus comparable to many of the lowland rain forests in South East Asia (Kiese et al., 2003). For further information about site properties, see Kiese and Butterbach-Bahl (2002) and Table 1. In this study, we used a full year dataset on nitrous oxide emissions and methane uptake as recorded for the period from 1 November 2001, to 31 October 2002. Details of the measuring system and modes of calibration have already been described by Kiese and Butterbach-Bahl (2002), and Kiese et al. (2003). Measurements of climate parameters were recorded by an on-site climate station. In this study, daily air temperature and rainfall data were used to simulate soil moisture (vol\%) and soil temperature time series for $10 \mathrm{~cm}$ soil depth which were only sporadically recorded - by the ForestDNDC (DeNitrification-DeComposition)-tropica model. Simulated soil moisture and soil temperature values agreed with observed data by $\pm 3 \%$ WFPS (water-filled pore space) or $\pm 1^{\circ} \mathrm{C}$, respectively. The model itself has been successfully evaluated for this site for its predicting capability with regard to nitrous oxide fluxes and soil environmental conditions in earlier studies (Kiese et al., 2005; Werner et al., 2007b).

Nitrous oxide and methane flux data for temperate semiarid steppe were obtained at a site in the Xilin River catchment near the Inner Mongolia Grassland Ecosystem Research Station (IMGERS), Chinese Ecosystem Research Network. Additional details of the site are provided by Liu et al. (2007), Chen et al. $(2010,2011)$ and in Table 1. The full year dataset on methane and nitrous oxide fluxes was obtained in the period of time between 15 August 2007 and 15 August 2008. Details on flux measurements can be found in Wolf et al. (2010) and Chen et al. (2010). Soil temperature (at $5 \mathrm{~cm}$ soil depth) as well as volumetric water content of the topsoil (at 0-6 cm soil depth) were continuously recorded in 1 min intervals using PT100 thermocouples (Th2-h; UMS $\mathrm{GmbH}$, Munich, Germany) or ECH2O FD probes (Decagon
Devices, Pullman, WA, USA), respectively. During the wintertime, when soil temperatures dropped below zero degree, topsoil (at $0-5 \mathrm{~cm}$ soil depth) samples were taken at least twice a week for the determination of volumetric water content.

Flux data as well as measurements of soil moisture/ soil temperature at all sites were obtained in subdaily resolution either in approx. 2-hourly (fluxes) or in even shorter time intervals (temperature/moisture). In this study we only use daily average values.

\subsection{Statistics}

The software packages SPSS 8.0 (SPSS Inc., Chicago, USA) and SigmaPlot 10.0 (Systat Software Inc., Chicago, USA) were used for statistical data analysis. Annual methane and nitrous oxide fluxes represent the amount of cumulative uptake and emission using a linear interpolation approach. As each site is subject to different climate and site characteristics (see Introduction and Materials and methods), different averages and ranges of fluxes, soil temperature, and moisture were observed. Therefore, flux (nitrous oxide and methane) as well as environmental data (soil temperature and moisture) for each study site were normalized to values ranging between 0 and 1 in Origin 7.0 (Origin Lab Corporation, USA) before exploring relationships between trace gas fluxes and both soil moisture and temperature to allow a comparison across these different sites. Note that before normalization of methane uptake rate values were multiplied by $(-1)$.

\section{Results}

\subsection{Temporal variability of climate, methane uptake, and nitrous oxide emission}

All three sites have shown a pronounced seasonal variability in soil temperature and moisture (Figs. 1-3). The seasonal variability in soil temperature conditions was highest for the steppe site in Inner Mongolia (Figs. 2, 4) with a minimum of $-11.3^{\circ} \mathrm{C}$ (January 29,2008 ) and a maximum of $25.6^{\circ} \mathrm{C}$ (July 19,2008 ) at a soil depth of $5 \mathrm{~cm}$. Variability of 


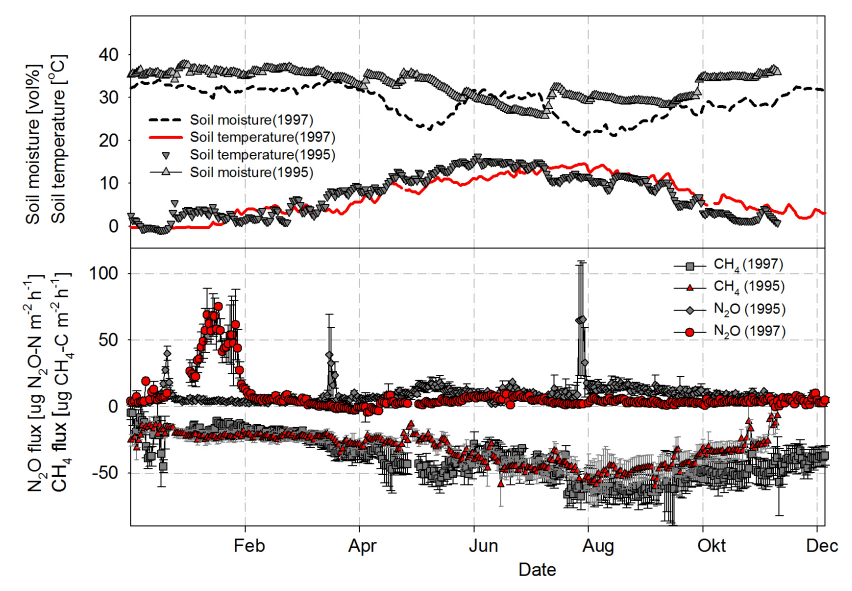

Fig. 1. Seasonal variability of daily average soil volumetric water content (at $10 \mathrm{~cm}$ depth) and soil temperature (at $5 \mathrm{~cm}$ depth) as well as of soil nitrous oxide and methane fluxes at the Höglwald Forest site in the years 1995 and 1997.

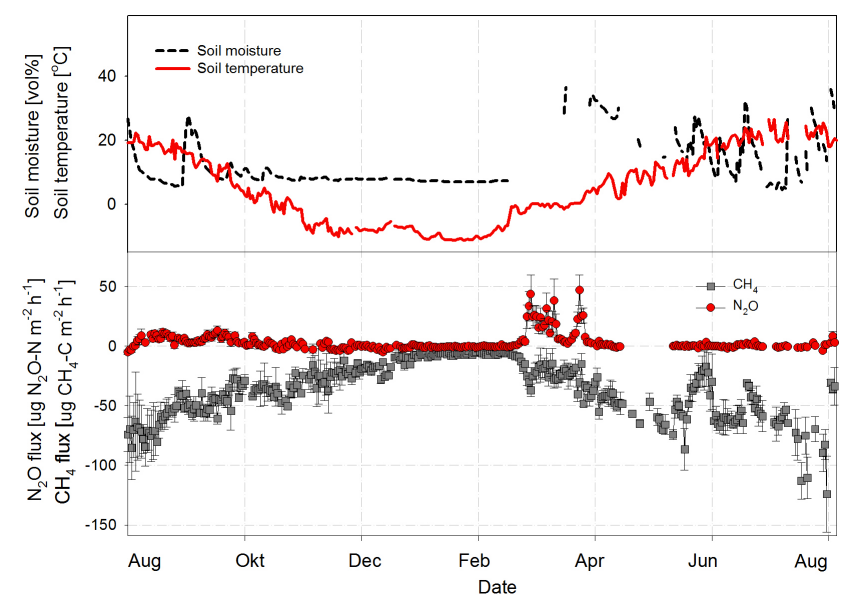

Fig. 2. Seasonal variability of daily average soil volumetric water content (at $0-6 \mathrm{~cm}$ depth) and soil temperature (at $5 \mathrm{~cm} \mathrm{depth)} \mathrm{as}$ well as of soil nitrous oxide and methane fluxes at the semi-arid steppe site in Inner Mongolia for the period 15 August 2007 to 15 August 2008.

soil temperature $\left(11^{\circ} \mathrm{C}\right.$ at a soil depth of $\left.10 \mathrm{~cm}\right)$ was lowest for the tropical rainforest site at Bellenden Ker (Figs. 3, 4) with minimum values of $16^{\circ} \mathrm{C}$. However, variability of soil moisture was significantly higher at the tropical forest site (soil volumetric water content: $7.5 \%$ to $37.4 \%$ at $10 \mathrm{~cm}$ soil depth), but lowest for the temperate spruce forest site at Höglwald Forest (soil volumetric water content: $21.1 \%$ to $31.1 \%$ at $10 \mathrm{~cm}$ soil depth in the year 1997) (Figs. 1-4).

The pronounced variability in soil environmental conditions was mirrored by an evident variability in soil nitrous oxide and methane fluxes. Figures 1-3 show that at the temperate forest site as well as at the semi-arid steppe site, highest nitrous oxide fluxes were observed during the spring-thaw period (temperate forest up to $80 \mu \mathrm{g} \mathrm{N} \mathrm{m}{ }^{-2} \mathrm{~h}^{-1}$; steppe up

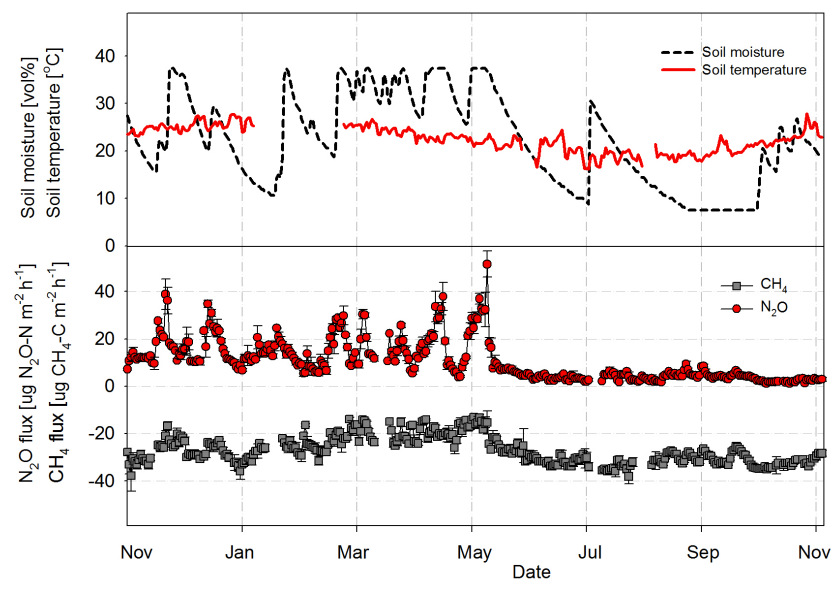

Fig. 3. Seasonal variability of daily average soil volumetric water content (at $10 \mathrm{~cm}$ depth) and soil temperature (at $10 \mathrm{~cm}$ depth) as well as of soil nitrous oxide and methane fluxes at the tropical forest site Bellenden Ker, Queensland, Australia, for the period 2 November 2001 to 31 October 2002.

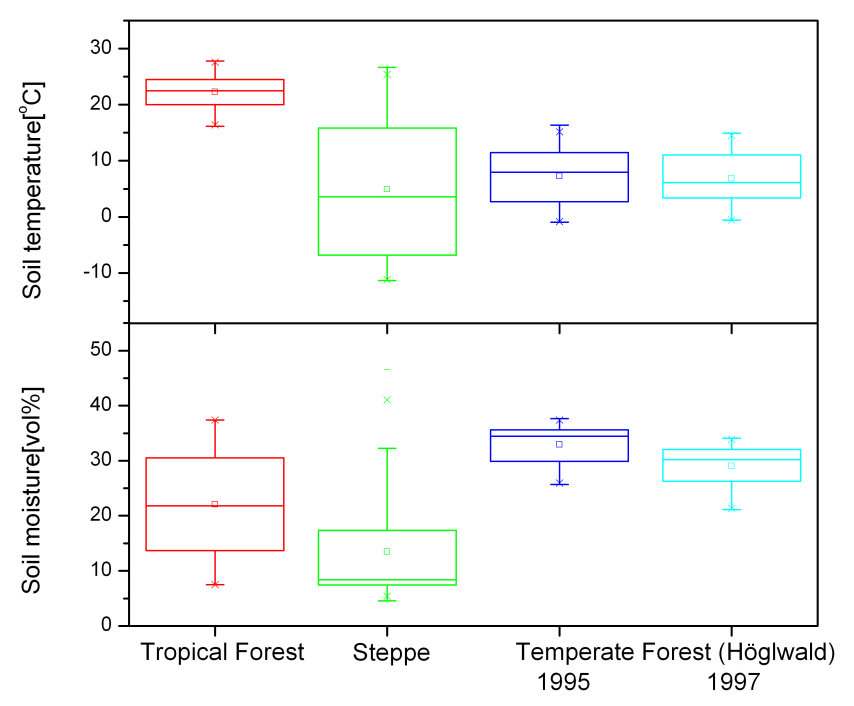

Fig. 4. Box plot of average daily soil volumetric water content and soil temperature for the three investigated ecosystem types: tropical forest, semi-arid steppe, and temperate forest (Höglwald forest: data both in years 1995 and 1997). The boxes are determined by 25th and 75 th percentiles. The whiskers are determined by the 5th and 95th percentiles. Additional values can be represented in box chart, including the minimum and maximum (dashes), median (line in the box), mean (square), 1st percentile and 99th percentiles (crosses)

to $50 \mu \mathrm{g} \mathrm{N} \mathrm{m}^{-2} \mathrm{~h}^{-1}$ ). However, during the vegetation period, hardly any variability of nitrous oxide fluxes was observed (Figs. 1, 2). In contrast, nitrous oxide fluxes at the tropical forest site were obviously linked to changes in soil moisture (up to $50 \mu \mathrm{g} \mathrm{N} \mathrm{m}^{-2} \mathrm{~h}^{-1}$ in the wet season) and were between 5 and $10 \mu \mathrm{N} \mathrm{m}^{-2} \mathrm{~h}^{-1}$ during the dry season from May 2002 to November 2002 (Fig. 3). 


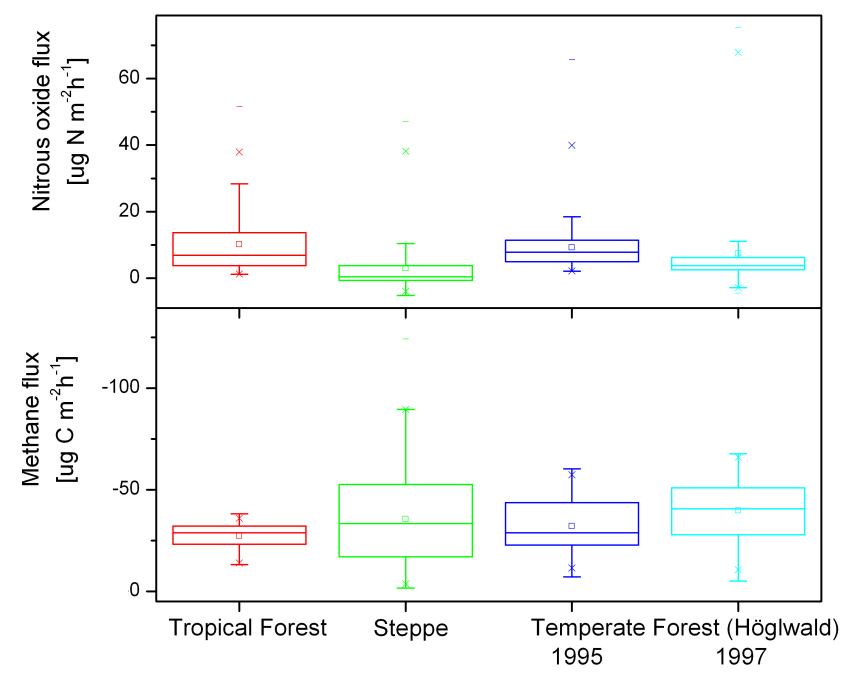

Fig. 5. Box plot of daily average soil nitrous oxide and methane fluxes in tropical forest, semi-arid steppe, and temperate forest (Höglwald: data from both years 1995 and 1997). The boxes are determined by 25 th and 75 th percentiles. The whiskers are determined by the 5th and 95th percentiles. Additional values can be represented in box chart, including the minimum and maximum (dashes), median (line in the box), mean (square), 1st percentile and 99th percentiles (crosses).

Methane uptake at the semi-arid steppe and temperate forest sites in general followed the course of soil temperature with maximum uptake rates in summer (steppe: $-125 \mu \mathrm{g} \mathrm{C} \mathrm{m}^{-2} \mathrm{~h}^{-1}$; temperate forest: $-70 \mu \mathrm{g} \mathrm{C} \mathrm{m} \mathrm{C}^{-2} \mathrm{~h}^{-1}$ ). This seasonality was modified by changes in soil moisture, with periods of high soil moisture values leading to lower methane uptake rates. For the tropical forest site, an effect of soil temperature on methane uptake is not directly visible. Rather, uptake rates are mainly linked to changes in soil moisture with the highest rates of methane uptake $\left(-40 \mu \mathrm{g} \mathrm{m}^{-2} \mathrm{~h}^{-1}\right)$ during the dry period from May to November 2002.

Besides differences in the seasonality and dynamics of methane and nitrous oxide fluxes to changes in soil environmental conditions, there were also distinct differences in the overall magnitude of observed fluxes across the three study sites. Annual cumulative nitrous oxide fluxes for the different ecosystems varied at a range of $0.2-1.0 \mathrm{~kg} \mathrm{~N}_{2} \mathrm{O}$ $\mathrm{N} \mathrm{ha}^{-1} \mathrm{yr}^{-1}$ and were decreasing in the following sequence: tropical rainforest $>$ temperate forest $\gg$ semi-arid steppe (Table 2). Soil methane uptake rates varied at a range of -2.4 to $-3.5 \mathrm{~kg} \mathrm{CH}_{4}-\mathrm{Cha}^{-1} \mathrm{yr}^{-1}$ in the following sequence: temperate forest $\approx$ semi-arid steppe $>$ tropical forest (Table 2 ).

A comparison of soil nitrous oxide and methane flux characteristics for the three investigated ecosystems is presented in Fig. 5. For the semi-arid steppe, the largest variations in methane oxidation rates were observed, whereas the annual variability of methane uptake was lowest for the tropical rainforest site. In contrast to the variability of methane uptake, the nitrous oxide flux variability was highest for the tropical rainforest site. However, in the semi-arid steppe and temperate forest ecosystems distinct peak emissions were observed during freezing and thawing periods.

\subsection{Effects of soil temperature and moisture on methane and nitrous oxide fluxes}

Combined effects of soil moisture and temperature on methane and nitrous oxide fluxes are depicted in Figs. 6-8. The contour graphs for nitrous oxide (Fig. 6) show that maximum nitrous oxide fluxes at the temperate forest and semiarid steppe sites were observed during freeze-thaw periods when the soil was cold but wet. When the freeze-thaw periods were excluded (Fig. 7), highest nitrous oxide fluxes occurred during warm and wet periods in the temperate forest, and during warm and dry periods (following a few days after rainfall events (data not shown)) at the steppe site. Due to a weak correlation of nitrous oxide fluxes with soil temperature, highest emissions in the tropical rainforest were generally observed at high soil moisture, independent of the soil temperature (Fig. 7).

In both the tropical rain forest and temperate forest sites, changes in soil temperature and moisture were controlling methane uptake rates (Fig. 8). While at the temperate forest site maximum uptake rates were clearly associated with lowest soil moisture and highest soil temperature, methane uptake rates at the tropical forest site showed a bimodal distribution (Fig. 8). The first optimum was in line with observations for the temperate forest, i.e. high soil temperature and low soil moisture. However, a second optimum with even higher methane uptake rates was found for conditions with comparable lower soil temperatures and slightly elevated soil moisture (normalized values of soil temperature and moisture of approximately 0.4 ). For the semi-arid steppe site, contour lines are running approximately parallel to the y-axis, which represents the soil moisture vector. This shows that a significant effect of soil moisture changes on methane uptake rates is not visible, at least for the range of soil moisture conditions underlying this analysis.

Regression analyses using normalized data has shown for all sites that combined changes in soil temperature and soil moisture exert a stronger control on methane uptake ( $R^{2}$ values: $0.67-0.77$; Table 3 ) as on nitrous oxide emission ( $R^{2}$ values: $0.19-0.41$; Table 4). However, if soil moisture and temperature effects on nitrous oxide fluxes are analysed for freeze-thaw periods (only 1997 dataset for the temperate forest site and the steppe dataset), the predicting power of a simple soil moisture-soil temperature relationship for nitrous oxide fluxes increases remarkably $\left(R^{2}: 0.71-0.77\right)$ (Table 5). 
Table 3. Temperature and moisture control on methane fluxes.

\begin{tabular}{|c|c|c|c|c|c|c|c|c|c|}
\hline Predictors & Ecosystems & Functions & $a$ & $b$ & $c$ & $x 0$ & $y 0$ & $n$ & $R^{2}$ \\
\hline \multirow{3}{*}{ soil temperature $(T)$} & steppe & \multirow{3}{*}{ Gaussian: $f=a \times \exp \left(-, 5 \times((T-x 0) / b)^{2}\right) \times(-1)$} & $0.50^{* * *}$ & $0.56^{* * *}$ & & $1.05^{* * *}$ & & 259 & $0.71^{* * *}$ \\
\hline & rain forest & & - & - & & - & & - & - \\
\hline & temperate forest & & $0.66^{* * *}$ & $0.51^{* * *}$ & & $0.83^{* * *}$ & & 300 & $0.49^{* * *}$ \\
\hline \multirow{3}{*}{ soil moisture $(M)$} & steppe & \multirow{3}{*}{ Gaussian: $f=a \times \exp \left(-0.5 \times((M-x 0) / b)^{2}\right) \times(-1)$} & $0.45^{* * *}$ & $0.24^{* * *}$ & & $0.36^{* * *}$ & & 259 & $0.22^{* * *}$ \\
\hline & rain forest & & $0.77^{* * *}$ & $0.47^{* * *}$ & & $0.25^{* * *}$ & & 277 & $0.67^{* * *}$ \\
\hline & temperate forest & & $0.88^{* * *}$ & $0.54^{* * *}$ & & -0.0036 & & 300 & $0.70^{* * *}$ \\
\hline \multirow{3}{*}{$\begin{array}{l}\text { soil temperature }(T) \text {, } \\
\text { soil moisture }(M)\end{array}$} & steppe & \multirow{3}{*}{$\begin{array}{l}\text { Gaussian: } \\
f=a \times \exp \left(-, 5 \times\left(((T-x 0) / b)^{2}+((M-y 0) / c)^{2}\right)\right) \times(-1)\end{array}$} & $0.54^{* * *}$ & $0.52^{* * *}$ & 1.17 & $0.99^{* * *}$ & -0.23 & 259 & $0.73^{* * *}$ \\
\hline & rain forest & & 2.73 & 11.19 & $0.45^{* * *}$ & -17.27 & $0.27^{* * *}$ & 277 & $0.67^{* * *}$ \\
\hline & temperate forest & & $0.92^{* * *}$ & $0.55^{* * *}$ & $0.65^{* * *}$ & $0.67^{* * *}$ & -0.067 & 300 & $0.77^{* * *}$ \\
\hline
\end{tabular}

*** $p<0.0001$.

- no significant regression results.

Table 4. Temperature and moisture control on nitrous oxide fluxes. Note that for these analyses, freeze and thaw periods were excluded (steppe and temperate forest site 1997).

\begin{tabular}{|c|c|c|c|c|c|c|c|c|c|}
\hline Predictors & Ecosystems & Functions & $a$ & $b$ & $c$ & $x 0$ & $y 0$ & $n$ & $R^{2}$ \\
\hline soil temperature $(T)$ & $\begin{array}{l}\text { steppe } \\
\text { rain forest } \\
\text { temperate forest }\end{array}$ & $\ln (f)=a T+x 0$ & $\begin{array}{l}0.17^{* * *} \\
-0.57^{* * *} \\
0.13^{* * *}\end{array}$ & & & $\begin{array}{l}0.57^{* * *} \\
0.77^{* * *} \\
0.70^{*}\end{array}$ & & $\begin{array}{l}241 \\
290 \\
262\end{array}$ & $\begin{array}{l}0.15^{* * *} \\
0.33^{* * *} \\
0.10^{* * *}\end{array}$ \\
\hline $\begin{array}{l}\text { soil temperature }(T) \text {, } \\
\text { soil moisture }(M)\end{array}$ & $\begin{array}{l}\text { steppe } \\
\text { rain forest } \\
\text { temperate forest }\end{array}$ & $\ln (f)=a \times T+b \times M+y 0$ & $\begin{array}{l}0.23^{* * *} \\
-0.41^{* * *} \\
0.25^{* * *}\end{array}$ & $\begin{array}{l}-0.18^{* *} \\
-0.22^{* * *} \\
0.20^{* * *}\end{array}$ & & & $\begin{array}{l}0.59^{* * *} \\
0.80^{* * *} \\
0.52 * * *\end{array}$ & $\begin{array}{l}241 \\
290 \\
262\end{array}$ & $\begin{array}{l}0.19^{* * *} \\
0.41^{* * *} \\
0.21^{* * *}\end{array}$ \\
\hline
\end{tabular}

-: no significant regression results.

***: $p<0.0001, * *: p<0.001,{ }^{*}: p<0.05$.

\subsection{Ecosystem cross-comparison of fluxes and drivers}

For cross-comparison of ecosystems we used the normalized data as shown in Figs. 9-11. Using all data, including nitrous oxide fluxes during freeze-thaw periods, the crossecosystem analysis reveals that two optima for high nitrous oxide emissions exist: (a) for warm and moist conditions and (b) for wet and cold conditions (Fig. 9). Excluding freezethaw nitrous oxide emissions from the cross-ecosystem analysis reveals that maximum nitrous oxide fluxes are unequivocally associated with warm and wet soil conditions (Fig. 10).

The contour plot for methane uptake fluxes with normalized data from all three ecosystems (Fig. 11) shows that the highest methane uptake rates can be expected for average annual soil environmental conditions. The highest uptake rates were predicted for soil temperature conditions representing $50-70 \%(0.5-0.7$ in Fig. 11) of the observed temperature range at a given site or $30-50 \%(0.3-0.5$ in Fig. 11) with regard to soil moisture.

\section{Discussion}

\subsection{Controls of nitrous oxide emission}

Nitrous oxide is mainly a product of two key nitrogen cycling processes in soil: nitrification (the oxidation of ammonium to nitrite and nitrate) and denitrification (the reduction of nitrate and nitrite to nitric oxide, nitrous oxide, and dinitrogen). The magnitude of fluxes largely depends on soil environmental conditions, with temperature and soil moisture, besides substrate availability, being major determinants. For the years being evaluated here, annual nitrous oxide fluxes were highest for the rainforest site $\left(0.96 \mathrm{~kg} \mathrm{Nha}^{-1} \mathrm{yr}^{-1}\right)$, somewhat lower for the atmospheric $\mathrm{N}$ deposition affected temperate forest site Höglwald $\left(0.67 \mathrm{~kg} \mathrm{Nha}^{-1} \mathrm{yr}^{-1}\right)$, and lowest for the steppe site in Inner Mongolia $\left(0.22 \mathrm{~kg} \mathrm{~N} \mathrm{ha}^{-1} \mathrm{yr}^{-1}\right)$. The mentioned annual emission rates are within the range of reported nitrous oxide fluxes for the specific ecosystem types (see e.g. for tropical forests: Breuer et al., 2000; temperate forests: Bouwman et al., 1995; Brumme and Beese, 1992; and steppe ecosystems: Galbally et al., 2008). 
Table 5. Regression results between nitrous oxide fluxes and both soil temperature and soil moisture for freeze and thaw periods as observed in the dataset of the steppe site and the temperate forest site (only in the dataset of the year 1997).

\begin{tabular}{|c|c|c|c|c|c|c|c|c|c|}
\hline Predictors & Ecosystems & Functions & $a$ & $b$ & $c$ & $x 0$ & $y 0$ & $n$ & $R^{2}$ \\
\hline \multirow{2}{*}{ soil temperature $(T)$} & steppe & & $0.71^{* * *}$ & $0.15^{* * *}$ & & $0.25^{* * *}$ & & 27 & $0.54^{* * *}$ \\
\hline & temperate forest & $f=a \times \exp \left(-, 5 \times((T-x 0) / b)^{2}\right)$ & $0.87^{* * *}$ & $0.19^{* * *}$ & & $0.33^{* * *}$ & & 81 & $0.50^{* * *}$ \\
\hline \multirow{2}{*}{ soil moisture $(M)$} & steppe & \multirow{2}{*}{$f=a \times \exp \left(-, 5 \times((M-x 0) / b)^{2}\right)$} & $0.93^{* * *}$ & $0.36^{* * *}$ & & $0.88^{* * *}$ & & 27 & $0.7^{* * *}$ \\
\hline & temperate forest & & $0.92 *$ & $0.35^{*}$ & & -0.07 & & 81 & $0.32^{* * *}$ \\
\hline \multirow{2}{*}{$\begin{array}{l}\text { soil temperature }(T) \text {, } \\
\text { soil moisture }(M)\end{array}$} & steppe & \multirow{2}{*}{$f=a \times \exp \left(-, 5 \times\left(((T-x 0) / b)^{2}+((M-y 0) / c)^{2}\right)\right)$} & $1.05^{* *}$ & $0.20^{* *}$ & $0.54^{*}$ & $0.27^{* * *}$ & $1.01 *$ & 27 & $0.77^{* * *}$ \\
\hline & temperate forest & & $1.18^{* * *}$ & $0.21^{* * *}$ & $0.31^{* * *}$ & $0.27^{* * *}$ & $0.23^{* * *}$ & 81 & $0.71^{* * *}$ \\
\hline
\end{tabular}

- no significant regression results.

*** $p<0.0001,{ }^{* *} p<0.001,^{*} p<0.05$.
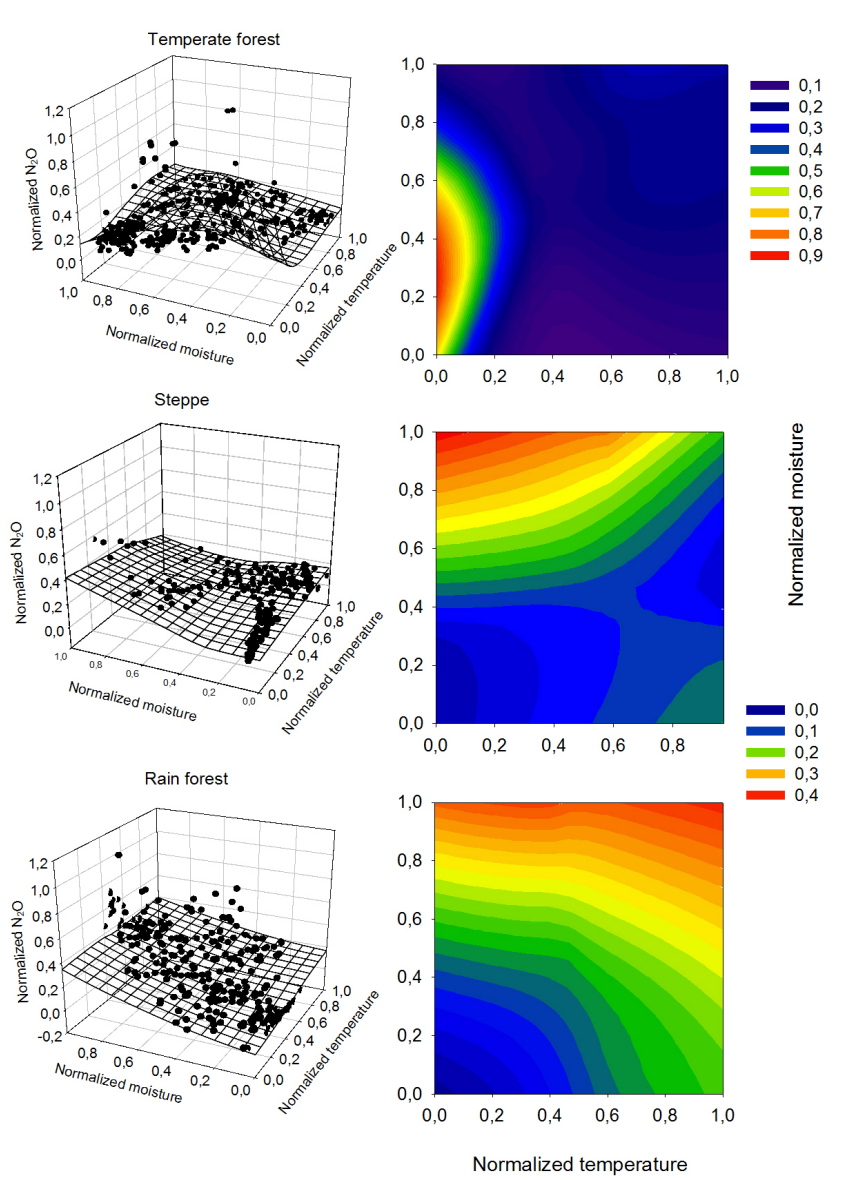

Fig. 6. Temperature and moisture effects on soil nitrous oxide fluxes for the three different ecosystems (temperate forest, semiarid steppe, and tropical rain forest). Freeze and thaw periods were included. For this analysis nitrous oxide fluxes, soil temperature, and moisture data were normalized at site scale to a range of $0-1$ ( 0 : lowest observed value; 1 : highest observed value). Nitrous oxide data for Höglwald Forest were randomly selected from observations in the years 1995 and 1997. Prior to the calculation of contour lines, data were smoothed with the loess algorithm or negative exponential algorithm (sampling proportion 0.6-1.0).

Soil nitrous oxide fluxes have been observed to increase exponentially with soil temperature (Brumme, 1995; Dins- more et al., 2009; Schindlbacher et al., 2004; Smith et al., 2003), which can be explained by a combination of an expansion in anaerobic zones triggered by the acceleration of soil respiration, the increasing denitrification rate per unit of anaerobic volume (Smith et al., 2003), and the temperature sensitivity of the underlying enzymatic processes. Accordingly, moisture effects on soil nitrous oxide fluxes are a result of the limitations of $\mathrm{O}_{2}$ diffusion into the soil and expansion of soil anaerobiosis, which in turn promotes reductive microbial processes such as denitrification. At our temperate forest site, temperature and moisture effects were both important with regard to inducing temporal changes in nitrous oxide fluxes. For the steppe site, temperature was the dominant driver, and for the tropical forest site soil moisture was the dominant driver of the daily variability in nitrous oxide fluxes (Fig. 7, Table 4). However, the explanatory power of relationships of soil moisture or soil temperature to nitrous oxide fluxes remained rather poor $\left(R^{2} \leq 0.33\right)$. Even for the tropical forest site in our study, combined changes in soil moisture and soil temperature could only explain less than $50 \%$ of the observed temporal variations in nitrous oxide fluxes, indicating that other controlling factors such as $\mathrm{N}$ and $\mathrm{C}$ availability (e.g. Morley and Baggs, 2010; Pilegaard et al., 2006) or microbial community dynamics (e.g. Regan et al., 2011) exert a significant control on the temporal dynamic of nitrous oxide fluxes as well. This lack of predictive power of simple relationships between environmental drivers and nitrous oxide fluxes for long-period datasets, spanning at least one year, has been observed for other natural and seminatural systems as well, e.g. for temperate humid grassland systems in Germany (Kammann et al., 2008), prairie systems in North America (Mosier et al., 1996) or a mixed forest in a mountainous region in Austria (Kitzler et al., 2006). This represents that important regulating factors such as moisture and temperature might have both synergistic and antagonistic effects on the status of other regulating factors. Thus we cannot expect a simple relationship between them and the pattern in the rate of emissions associated with denitrification or nitrification in the soils. For shorter observation periods, in our case nitrous oxide fluxes during freeze-thaw periods, stronger, non-linear correlations - specifically between nitrous oxide fluxes and soil moisture - can be found 

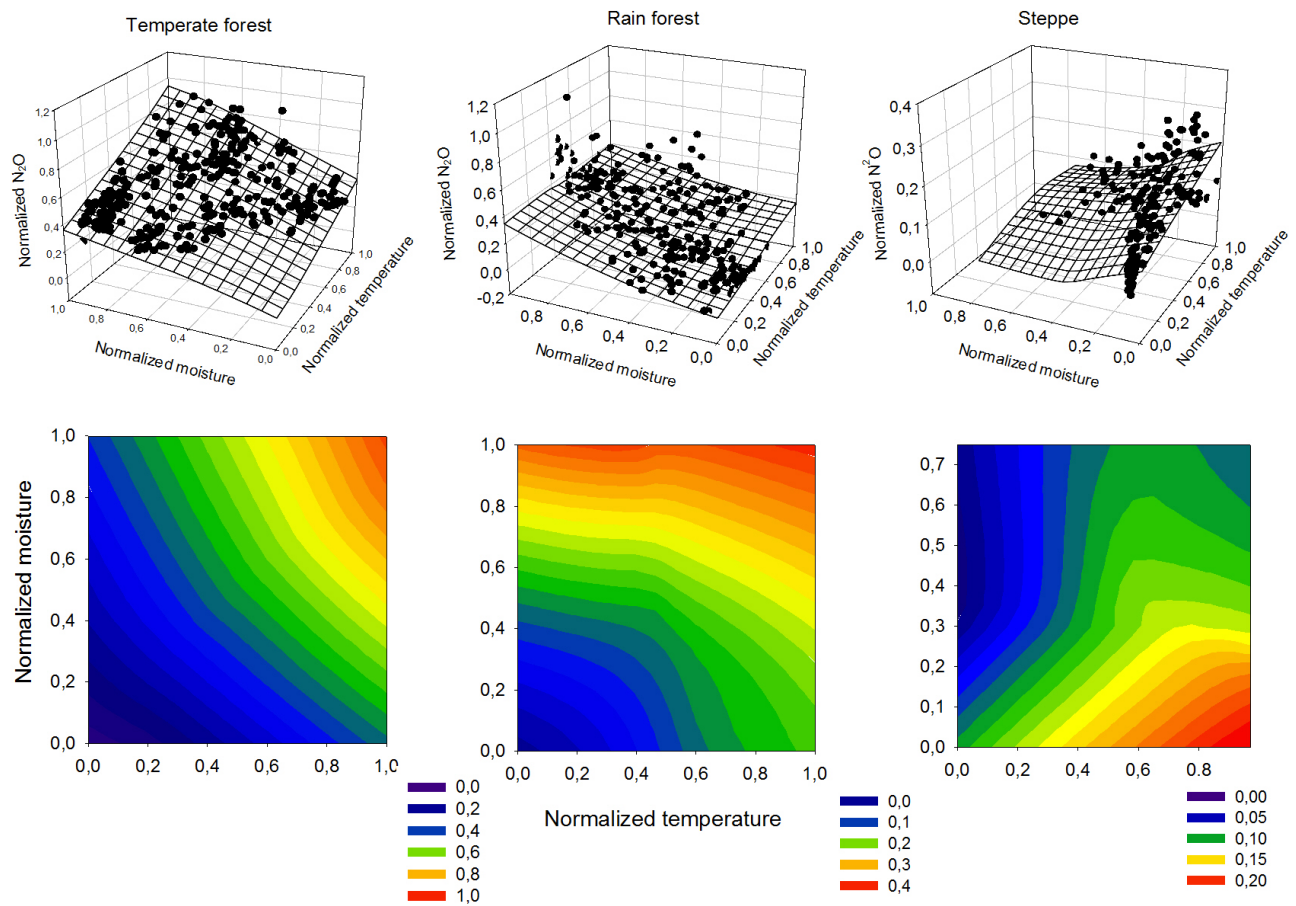

Fig. 7. Temperature and moisture effects on soil nitrous oxide fluxes for the three different ecosystems (temperate forest, semi-arid steppe, and tropical rain forest). For this analysis nitrous oxide fluxes, soil temperature, and moisture data were normalized at site scale to a range of 0-1 (0: lowest observed value; 1: highest observed value). Nitrous oxide data for the Höglwald Forest were randomly selected from observations in the years 1995 and 1997, though for this analysis nitrous oxide fluxes during the freeze-thaw period was excluded. Prior to the calculation of contour lines, data were smoothed with the loess algorithm (sampling proportion $=1$ ).
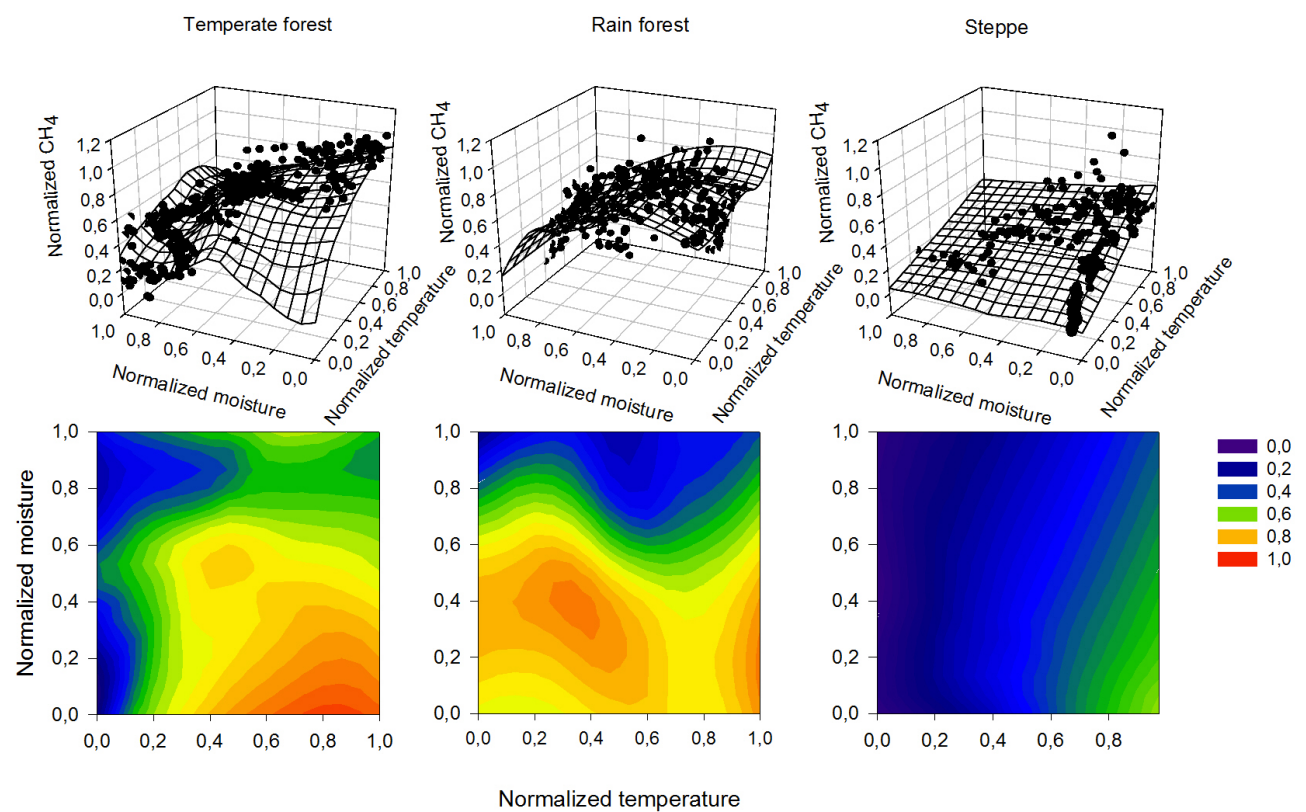

Fig. 8. Temperature and moisture effects on soil methane uptake rates for the three different ecosystems (temperate forest, semi-arid steppe, and tropical rain forest). For this analysis methane flux, soil temperature, and moisture data were normalized at site scale to a range of $0-1$ ( 0 : lowest observed value; 1 : highest observed value). Prior to the calculation of contour lines, data were smoothed with the loess algorithm or negative exponential algorithm (sampling proportion $0.3-0.6$ ). 

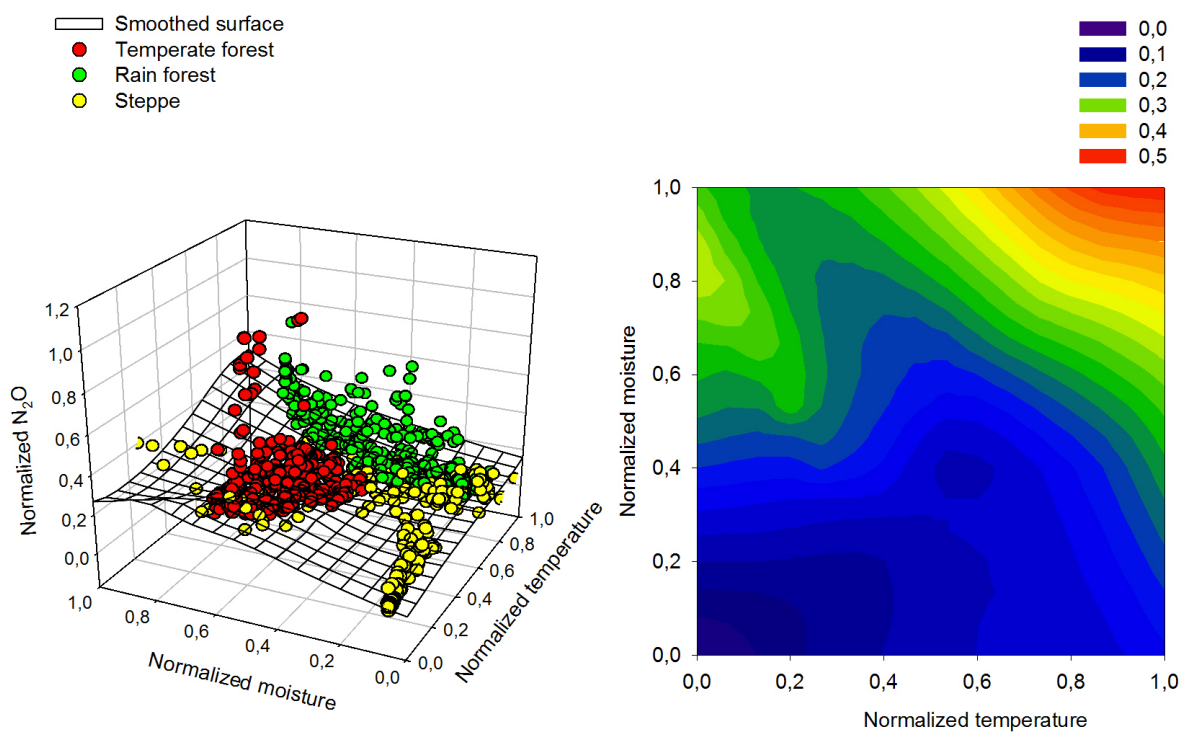

Fig. 9. Temperature and moisture effects on nitrous oxide fluxes (all data) across all three ecosystems (temperate forest, semi-arid steppe, and tropical forest). For this analysis soil moisture and soil temperature as well as nitrous oxide fluxes were first normalized across ecosystems to a range of $0-1$ ( 0 : lowest observed value in all ecosystems; 1 : highest observed value in all ecosystems). Prior to the calculation of contour lines, data were smoothed with the loess algorithm (sampling proportion $=0.6$ ). Data for temperate forest were randomly selected from observations in the years 1995 and 1997.
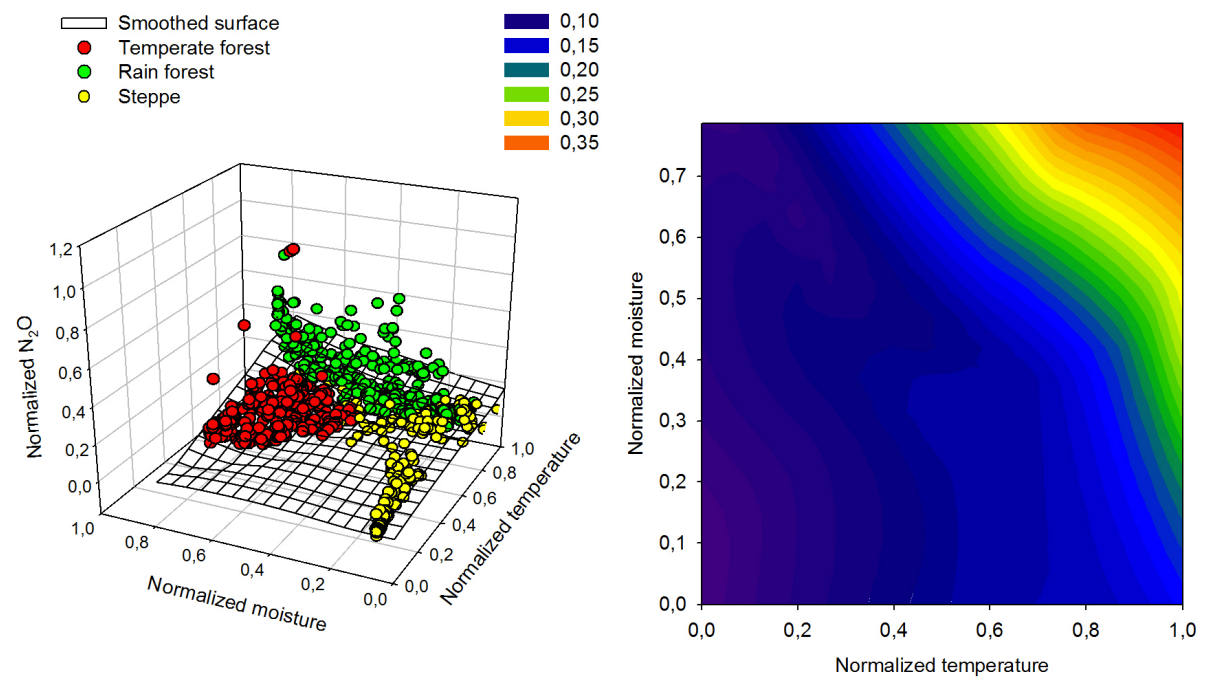

Fig. 10. Temperature and moisture effects on nitrous oxide fluxes (data for freeze-thaw periods at the temperate forest and steppe sites excluded) across all three ecosystems (temperate forest, semi-arid steppe, tropical forest). For this analysis soil moisture and soil temperature as well as nitrous oxide fluxes were normalized across ecosystems (see Fig. 9). Prior to the calculation of contour lines, data were smoothed with the loess algorithm (sampling proportion $=0.5$ ). Data for temperate forest were randomly selected from observations in the years 1995 and 1997.

(Table 5). Stronger correlations were also found when models with combined soil moisture and soil temperature were tested, a result that is in agreement with observations of soil nitrous oxide fluxes from a mixed forest in Austria (Kitzler et al., 2006).

\subsection{Controls of methane uptake}

Depending on climate, soil, ecosystem type, land use/management, all having impacts on soil aeration, oxygen, and methane availability, soils can either function as an atmospheric sink or source of methane (Topp and Pattey, 1997). The total sink strength of terrestrial ecosystems is 

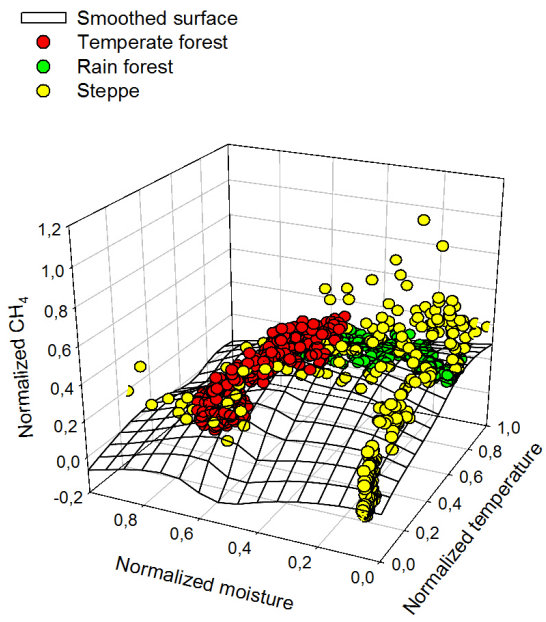

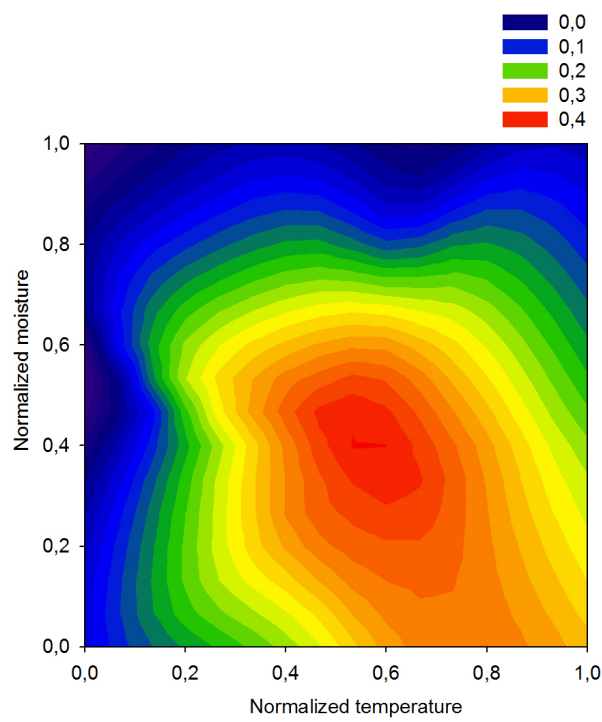

Fig. 11. Temperature and moisture effects on methane uptake fluxes across all three ecosystems (temperate forest, semi-arid steppe, and tropical forest). For this analysis, soil moisture and soil temperature as well as methane uptake flux data were normalized across ecosystems (see Fig. 9). Prior to the calculation of contour lines, data were smoothed with the loess algorithm (sampling proportion $=0.5$ ). Data for temperate forest were randomly selected for the observation years 1995 and 1997.

estimated to be approximately $15-45 \mathrm{Tg} \mathrm{yr}^{-1}$, which roughly equals the increase of atmospheric methane concentrations during the 1990s (Dutaur and Verchot, 2007). Observations that upland temperate and tropical forest as well as steppe soils serve as significant sinks for atmospheric methane have been confirmed in a large number of studies (Keller et al., 1983; Mosier et al., 1991; Seiler et al., 1984; Steudler et al., 1989; Whalen and Reeburgh, 1990). Topp and Pattey (1997) as well as Dutour and Verchot (2007) summarized representative methane fluxes for various ecosystem types including desert, temperate forest, tropical forest, and grass pasture. In their studies, annual uptake rates typically ranged from 0 to approximately $-20 \mathrm{~kg} \mathrm{CH}_{4}-\mathrm{Cha}^{-1} \mathrm{yr}^{-1}$ (mean: temperate forest: $-4.28 \mathrm{~kg} \mathrm{CH}_{4}-\mathrm{Cha}^{-1} \mathrm{yr}^{-1}$; tropical forest: $-2.50 \mathrm{~kg} \mathrm{CH}_{4}-\mathrm{Cha}^{-1} \mathrm{yr}^{-1}$; grassland: $-1.74 \mathrm{~kg} \mathrm{CH}_{4}-$ $\mathrm{Cha}^{-1} \mathrm{yr}^{-1}$ ) (Dutaur and Verchot, 2007). However, it still needs to be noted that most of these estimates are based on low measuring frequencies, often not covering a total year, which introduces high uncertainty to the estimation of annual uptake rates of methane. Values from our year-round observation in different ecosystems showed annual uptake of $-3.45 \mathrm{~kg} \mathrm{CH}_{4}-\mathrm{Cha}^{-1} \mathrm{yr}^{-1}$ (1997) and $-2.79 \mathrm{~kg} \mathrm{CH}_{4}-\mathrm{Cha}^{-1} \mathrm{yr}^{-1}$ (1995) for the temperate forest, $-2.38 \mathrm{kgCH}_{4}-\mathrm{Cha}^{-1} \mathrm{yr}^{-1}$ for the rain forest site, and $-3.39 \mathrm{~kg} \mathrm{CH}_{4}-\mathrm{Cha}^{-1} \mathrm{yr}^{-1}$ for the semi-arid steppe site. Annual fluxes are thus within (temperate and tropical forests) or at the high end (steppe) of previously published data for these ecosystem types.

Environmental controls of atmospheric methane uptake by soils have been assessed in many studies. For non-arable upland soils, (e.g. grassland or forest soils; Bowden et al., 1998;
Castro et al., 1994, 1995; Dunfield et al., 1995; Koschorreck and Conrad, 1993; van den Pol-van Dasselaar et al., 1998; Whalen and Reeburgh, 1996; Yavitt et al., 1995), temperature, soil gas permeability, and $\mathrm{N}$ availability were identified to be the primary controlling factors. Though atmospheric $\mathrm{N}$ deposition may also affect the methane uptake potential of a given site, specifically at the Höglwald Forest (Butterbach-Bahl and Papen, 2002), due to the ability of methanotrophic bacteria for $\mathrm{NH}_{4}^{+}$oxidation resulting in an inhibition of methane oxidation at elevated soil $\mathrm{NH}_{4}$ levels (Castro et al., 1995), this parameter is of little interest in the frame of this study with focus on a cross comparison of temporal controls of methane uptake for the three contrasting ecosystem types in this study.

Gas diffusion to the sites of actual methanotrophic activity, often found at $5-15 \mathrm{~cm}$ soil depth (Henckel et al., 2000; Roslev et al., 1997), has been identified for forest as well as for grassland ecosystems as the major rate-limiting step of methane uptake (Le Mer and Roger, 2001; Smith et al., 2003). Gas diffusion is controlled by site properties such as soil bulk density (Fujikawa and Miyazaki, 2005), soil structural features such as effective pore length and gas permeability (Liu et al., 2007), and the thickness and structure of the organic layer covering the mineral topsoil where methanotrophic activity is highest (Brumme and Borken, 1999). While the mentioned factors can be used to explain site differences in methane uptake activity between different forest types (Brumme and Borken, 1999; ButterbachBahl and Papen, 2002), seasonal variations in uptake activity have often been observed to be closely linked to soil moisture and the effect of soil moisture on soil gas permeability 
(e.g. incubation experiment: Bowden et al., 1998; Dunfield et al., 1995; Koschorreck and Conrad, 1993; van den Pol-van Dasselaar et al., 1998; Whalen and Reeburgh, 1996; e.g. field measurements: Castro et al., 1994, 1995; Yavitt et al., 1995).

Both at low and high soil moisture contents, methane uptake capacity may be suppressed, either by physiological water stress of methanotrophs or by restriction of diffusive methane and $\mathrm{O}_{2}$ transport (Del Grosso et al., 2000). The optimum soil water content for methane uptake is thought to reflect the balance between gas transport rates and physiological water stress. A further increase of soil moisture content may also increase soil methane production due to an increasing proportion of anaerobic sites (Butterbach-Bahl and Papen, 2002; Yavitt et al., 1995). At all of our sites, a close link of methane uptake to soil moisture fluctuations could be demonstrated. This was strongest for temperate forest (Table 3) and less pronounced at the steppe site. Since topsoil bulk densities are not significantly different across sites (Table 1), this can be explained best by the rather low amount of precipitation at the investigated steppe site (approximately $330 \mathrm{~mm}$ - the site with the lowest topsoil soil moisture), which seldom was sufficient to result in soil moisture levels critical for limiting gas diffusion (Table 2). At our temperate forest as well as at the rain forest site, oxidation of methane was hampered when soil moisture was higher than $60 \%$ of the moisture range (Fig. 8), which converted to WFPS values equals 44 and $43 \%$, respectively. This threshold value is comparable to a study by Sitaula et al. (1995) who found in their study on methane uptake by soils at a 100 yr-old Scots pine forest in Norway that an increase in soil moisture from 32 to $42 \mathrm{vol} \%$ resulted in a significant reduction of methane uptake. However, for Scottish woodland soils (Dobbie and Smith, 1996; Smith et al., 2000) with a sandy texture and a high porosity, oxidation rates were still high even at $80 \%$ WFPS, indicating that site specific soil properties and soil gas diffusion potentials control soil moisture thresholds for optimal $\mathrm{CH}_{4}$ uptake.

Rates of soil methane uptake increase with increasing soil temperature due to the temperature sensitivity of the underlying enzymatic process. This has been demonstrated in various field and laboratory studies (e.g. Bowden et al., 1998; Butterbach-Bahl and Papen, 2002; Steinkamp et al., 2001). Although temperature effects may be most pronounced for soil temperature $<15^{\circ} \mathrm{C}$, at higher temperatures gas diffusion limitations and drought effects may override temperature responses (e.g. Steinkamp et al., 2001). This explains why in our study only a weak effect of temperature on methane uptake could be found for the tropical forest, while the temperature effect is most pronounced at the steppe site (Table 3). For the latter site, the pronounced seasonality of methane uptake is thus a combination of temperature dependency (during autumn, winter and spring) and diffusion limitations due to occasional rainfall events and drought effects during prolonged periods limiting methanotrophic activity.

\subsection{Across-ecosystem commonalities}

In our across-ecosystem analyses as well as in our analyses on site scale we used daily average values of $\mathrm{N}_{2} \mathrm{O}$ and $\mathrm{CH}_{4}$ fluxes and soil moisture and temperature for the different sites to identify relationships between environmental drivers and soil $\mathrm{N}_{2} \mathrm{O}$ and $\mathrm{CH}_{4}$ fluxes. It should be noted that a further aggregation at weekly or monthly timescales will likely result in a weakening of displayed relationships as was e.g. shown for the Höglwald dataset by Luo et al. (2012).

Though there is a wealth of information available examining temporal and spatial variation of nitrous oxide and methane fluxes, a comparison of environmental response functions to contrast ecosystems in different climate zones has so far only rarely been undertaken. Multisite analyses of soil methane uptake for natural and managed systems have been presented (e.g. Smith et al., 2000), for forest soil nitrous oxide emissions by Pilegaard et al. (2006) and Schindlbacher et al. (2004), and for various ecosystem types by Schaufler et al. (2010). While the latter two publications are based on laboratory incubation studies allowing a more direct comparison of sites and flux magnitudes, the other mentioned studies are comparing field measurements at various sites. However, our study is to our knowledge the first study where a data generalization approach has been used to identify commonalities of effects of environmental drivers on methane and nitrous oxide fluxes. The generalization approach demonstrates that coherent patterns of methane uptake, soil moisture, and soil temperature exist across different ecosystems. We have strong evidence that optimum rates of methane uptake are found in environmental conditions representing approximately average site environmental conditions across these ecosystems. Thus, changes in soil environmental conditions (temperature/moisture) will likely reduce soil methane uptake potentials. This has rather important implications for understanding effects of climate change on soil methane uptake activity, since any shift in environmental conditions is likely to result in a reduction of methane uptake activity. For nitrous oxide, our analysis revealed expected patterns: highest nitrous oxide emissions under moist and warm conditions, and large nitrous oxide fluxes if soils are exposed to freeze-thawing effects at sufficiently high soil moisture contents.

Our approach of data generalization may prove beneficial for the development of environmental response models needed to better understand climate change feedbacks on biospheric sinks and sources of nitrous oxide and methane. However, the entire approach and its predictive power will depend on the availability of high quality flux datasets, which are currently available only for a few selected systems. 


\section{Conclusion}

Despite the huge number of flux measurements and modeling efforts at the process levels and field scales, it has proven difficult to establish strong predictive relationships between nitrous oxide and methane fluxes and environmental parameters such as temperature and moisture. The normalization approach of flux data and environmental parameters presented here allows for better identifying cross-ecosystem commonalities of drivers of trace gas fluxes from soils in natural and semi-natural environments. However, such an approach depends on high data quality and the accessibility of data to the wider research community. Our approach may contribute to the improvement of parameterization of models simulating biosphere-atmosphere exchange processes and evaluations of feedbacks of climate change on soil fluxes of nitrous oxide and methane.

Acknowledgements. The authors thank their colleagues for continuing support and Allison Kolar (IMK-IFU) for proof reading the manuscript. Part of the work was funded by the FP7 project InGOS and the DFG project BU1173/12-1.

The service charges for this open access publication

have been covered by a Research Centre of the

Helmholtz Association.

Edited by: G. Wohlfahrt

\section{References}

Bleakley, B. H. and Tiedje, J. M.: Nitrous-Oxide Production by Organisms Other Than Nitrifiers Or Denitrifiers, Appl. Environ. Microb., 44, 1342-1348, 1982.

Bouwman, A. F., Vanderhoek, K. W., and Olivier, J. G. J.: Uncertainties in the Global Source Distribution of Nitrous-Oxide, J. Geophys. Res., 100, 2785-2800, 1995.

Bowden, W. B.: Gaseous Nitrogen Emissions from Undisturbed Terrestrial Ecosystems - An Assessment of Their Impacts on Local and Global Nitrogen Budgets, Biogeochemistry, 2, 249-279, 1986.

Bowden, R. D., Newkirk, K. M., and Rullo, G. M.: Carbon dioxide and methane fluxes by a forest soil under laboratory-controlled moisture and temperature conditions, Soil Biol. Biochem., 30, 1591-1597, 1998.

Breuer, L., Papen, H., and Butterbach-Bahl, K.: $\mathrm{N}_{2}$ emission from tropical forest soils of Australia, J. Geophys. Res., 105, 2635326367, 2000.

Brumme, R.: Mechanisms of Carbon and Nutrient Release and Retention in Beech Forest Gaps, 3. Environmental-Regulation of Soil Respiration and Nitrous-Oxide Emissions Along A Microclimatic Gradient, Plant Soil, 168, 593-600, 1995.

Brumme, R. and Beese, F.: Effects of Liming and NitrogenFertilization on Emissions of $\mathrm{CO}_{2}$ and $\mathrm{N}_{2} \mathrm{O}$ from A Temporate Forest, J. Geophys. Res., 97, 12851-12858, 1992.
Brumme, R. and Borken, W.: Site variation in methane oxidation as affected by atmospheric deposition and type of temperate forest ecosystem, Global Biogeochem. Cy., 13, 493-501, 1999.

Butterbach-Bahl, K. and Papen, H.: Four years continuous record of $\mathrm{CH}_{4}$-exchange between the atmosphere and untreated and limed soil of a N-saturated spruce and beech forest ecosystem in Germany, Plant Soil, 240, 77-90, 2002.

Butterbach-Bahl, K., Gasche, R., Willibald, G., and Papen, H.: Exchange of $\mathrm{N}$-gases at the Hoglwald Forest - A summary, Plant Soil, 240, 117-123, 2002.

Butterbach-Bahl, K., Kock, M., Willibald, G., Hewett, B., Buhagiar, S., Papen, H., and Kiese, R.: Temporal variations of fluxes of $\mathrm{NO}, \mathrm{NO}_{2}, \mathrm{~N}_{2} \mathrm{O}, \mathrm{CO}_{2}$, and $\mathrm{CH}_{4}$ in a tropical rain forest ecosystem, Global Biogeochem. Cy., 18, GB3012, doi:10.1029/2004GB002243, 2004.

Castro, M. S., Melillo, J. M., Steudler, P. A., and Chapman, J. W.: Soil-Moisture As A Predictor of Methane Uptake by Temperate Forest Soils, Can. J. Forest Res., 24, 1805-1810, 1994.

Castro, M. S., Steudler, P. A., Melillo, J. M., Aber, J. D., and Bowden, R. D.: Factors Controlling Atmospheric Methane Consumption by Temperate Forest Soils, Global Biogeochem. Cy., 9, 110, 1995.

Chen, W. W., Wolf, B., Yao, Z. S., Bruggemann, N., ButterbachBahl, K., Liu, C. Y., Han, S. H., Han, X. G., and Zheng, X. H.: Annual methane uptake by typical semiarid steppe in Inner Mongolia, J. Geophys. Res., 115, D15108, doi:10.1029/2009JD013783, 2010.

Chen, W. W., Wolf, B., Zheng, X. H., Yao, Z. S., Butterbach-Bahl, K., Bruggemann, N., Liu, C. Y., Han, S. H., and Han, X. G.: Annual methane uptake by temperate semiarid steppes as regulated by stocking rates, aboveground plant biomass and topsoil air permeability, Glob. Change Biol., 17, 2803-2816, 2011.

Conrad, R.: Soil microorganisms as controllers of atmospheric trace gases $\left(\mathrm{H}_{2}, \mathrm{CO}, \mathrm{CH}_{4}, \mathrm{OCS}, \mathrm{N}_{2} \mathrm{O}\right.$, and $\left.\mathrm{NO}\right)$, Microbiol. Rev., 60, 609-640, 1996.

Del Grosso, S. J., Parton, W. J., Mosier, A. R., Ojima, D. S., Potter, C. S., Borken, W., Brumme, R., Butterbach-Bahl, K., Crill, P. M., Dobbie, K. and Smith, K. A.: General $\mathrm{CH}_{4}$ oxidation model and comparison of $\mathrm{CH}_{4}$ oxidation in natural and managed systems, Global Biogeochem. Cy., 14, 999-1020, 2000.

Dinsmore, K. J., Skiba, U. M., Billett, M. F., Rees, R. M., and Drewer, J.: Spatial and temporal variability in $\mathrm{CH}_{4}$ and $\mathrm{N}_{2} \mathrm{O}$ fluxes from a Scottish ombrotrophic peatland: Implications for modelling and up-scaling, Soil Biol. Biochem., 41, 1315-1323, 2009.

Dobbie, K. E. and Smith, K. A.: Comparison of $\mathrm{CH}_{4}$ oxidation rates in woodland, arable and set aside soils, Soil Biol. Biochem., 28, 1357-1365, 1996.

Dunfield, P. F., Topp, E., Archambault, C., and Knowles, R.: Effect of Nitrogen Fertilizers and Moisture-Content on $\mathrm{Ch}_{4}$ and $\mathrm{N}_{2} \mathrm{O}$ Fluxes in A Humisol - Measurements in the Field and Intact Soil Cores, Biogeochemistry, 29, 199-222, 1995.

Dutaur, L. and Verchot, L. V.: A global inventory of the soil $\mathrm{CH}_{4}$ sink, Global Biogeochem. Cy., 21, GB4013, doi:10.1029/2006GB002734, 2007.

Fujikawa, T. and Miyazaki, T.: Effects of bulk density and soil type on the gas diffusion coefficient in repacked and undisturbed soils, Soil Sci., 170, 892-901, 2005. 
Galbally, I. E., Kirstine, W. V., Meyer, C. P., and Wang, Y. P.: Soilatmosphere trace gas exchange in semiarid and arid zones, J. Environ. Qual., 37, 599-607, 2008.

Groffman, P. M., Brumme, R., Butterbach-Bahl, K., Dobbie, K. E., Mosier, A. R., Ojima, D., Papen, H., Parton, W. J., Smith, K. A., and Wagner-Riddle, C.: Evaluating annual nitrous oxide fluxes at the ecosystem scale, Global Biogeochem. Cy., 14, 1061-1070, 2000.

Henckel, T., Jackel, U., Schnell, S., and Conrad, R.: Molecular analyses of novel methanotrophic communities in forest soil that oxidize atmospheric methane, Appl. Environ. Microb., 66, 18011808, 2000.

Kammann, C., Muller, C., Grunhage, L., and Jager, H. J.: Elevated $\mathrm{CO}_{2}$ stimulates $\mathrm{N}_{2} \mathrm{O}$ emissions in permanent grassland, Soil Biol. Biochem., 40, 2194-2205, 2008.

Keller, M., Goreau, T. J., Wofsy, S. C., Kaplan, W. A., and Mcelroy, M. B.: Production of Nitrous-Oxide and Consumption of Methane by Forest Soils, Geophys. Res. Lett., 10, 1156-1159, 1983.

Kiese, R. and Butterbach-Bahl, $\mathrm{K} .: \mathrm{N}_{2} \mathrm{O}$ and $\mathrm{CO}_{2}$ emissions from three different tropical forest sites in the wet tropics of Queensland, Australia, Soil Biol. Biochem., 34, 975-987, 2002.

Kiese, R., Hewett, B., Graham, A., and Butterbach-Bahl, K.: Seasonal variability of $\mathrm{N}_{2} \mathrm{O}$ emissions and $\mathrm{CH}_{4}$ uptake by tropical rainforest soils of Queensland, Australia, Global Biogeochem. Cy., 17, 1043, doi:10.1029/2002GB002014, 2003.

Kiese R., Li C., Hilbert W., Papen H., and Butterbach-Bahl K.: Regional application of PnET-N-DNDC for estimating the $\mathrm{N}_{2} \mathrm{O}$ source strength of tropical rainforests in the Wet Tropics of Australia, Glob. Change Biol., 11, 128-144, 2005.

Kitzler, B., Zechmeister-Boltenstern, S., Holtermann, C., Skiba, U., and Butterbach-Bahl, K.: Controls over $\mathrm{N}_{2} \mathrm{O}, \mathrm{NO}_{\mathrm{x}}$ and $\mathrm{CO}_{2}$ fluxes in a calcareous mountain forest soil, Biogeosciences, 3 , 383-395, doi:10.5194/bg-3-383-2006, 2006.

Koschorreck, M. and Conrad, R.: Oxidation of Atmospheric Methane in Soil - Measurements in the Field, in Soil Cores and in Soil Samples, Global Biogeochem. Cy., 7, 109-121, 1993.

Kreutzer, K.: Effects of Forest Liming on Soil Processes, Plant Soil, 168, 447-470, 1995.

Le Mer, J. and Roger, P.: Production, oxidation, emission and consumption of methane by soils: A review, Eur. J. Soil Biol., 37, 25-50, 2001.

Liu, C. Y., Holst, J., Bruggemann, N., Butterbach-Bahl, K., Yao, Z. S., Yue, J., Han, S. H., Han, X., Krummelbein, J., Horn, R., and Zheng, X. H.: Winter-grazing reduces methane uptake by soils of a typical semi-arid steppe in Inner Mongolia, China, Atmos. Environ., 41, 5948-5958, 2007.

Luo, G. J., Brüggemann, N., Wolf, B., Gasche, R., Grote, R., and Butterbach-Bahl, K.: Decadal variability of soil $\mathrm{CO}_{2}, \mathrm{NO}$, $\mathrm{N}_{2} \mathrm{O}$, and $\mathrm{CH}_{4}$ fluxes at the Höglwald Forest, Germany, Biogeosciences, 9, 1741-1763, doi:10.5194/bg-9-1741-2012, 2012.

Morley, N. and Baggs, E. M.: Carbon and oxygen controls on $\mathrm{N}_{2} \mathrm{O}$ and N2 production during nitrate reduction, Soil Biol. Biochem., 42, 1864-1871, 2010.

Mosier, A., Schimel, D., Valentine, D., Bronson, K., and Parton, W.: Methane and Nitrous-Oxide Fluxes in Native, Fertilized and Cultivated Grasslands, Nature, 350, 330-332, 1991.

Mosier, A. R., Parton, W. J., Valentine, D. W., Ojima, D. S., Schimel, D. S., and Delgado, J. A.: $\mathrm{CH}_{4}$ and $\mathrm{N}_{2} \mathrm{O}$ fluxes in the
Colorado shorgrass steppe.1. Impact of landscape and nitrogen addition, Global Biogeochem. Cy., 10, 387-399, 1996.

Peterjohn, W. T., Melillo, J. M., Steudler, P. A., Newkirk, K. M., Bowles, F. P., and Aber, J. D.: Responses of Trace Gas Fluxes and $\mathrm{N}$ Availability to Experimentally Elevated Soil Temperatures, Ecol. Appl., 4, 617-625, 1994.

Pilegaard, K., Skiba, U., Ambus, P., Beier, C., Brüggemann, N., Butterbach-Bahl, K., Dick, J., Dorsey, J., Duyzer, J., Gallagher, M., Gasche, R., Horvath, L., Kitzler, B., Leip, A., Pihlatie, M. K., Rosenkranz, P., Seufert, G., Vesala, T., Westrate, H., and Zechmeister-Boltenstern, S.: Factors controlling regional differences in forest soil emission of nitrogen oxides ( $\mathrm{NO}$ and $\mathrm{N}_{2} \mathrm{O}$ ), Biogeosciences, 3, 651-661, doi:10.5194/bg-3-651-2006, 2006.

Peel, M. C., Finlayson, B. L., and McMahon, T. A.: Updated world map of the Köppen-Geiger climate classification, Hydrol. Earth Syst. Sci., 11, 1633-1644, doi:10.5194/hess-11-16332007, 2007.

Regan, K., Kammann, C., Hartung, K., Lenhart, K., Müller, C., Philippot, L., Kandeler, E., and Marhan, S.: Can differences in microbial abundances help explain enhanced $\mathrm{N}_{2} \mathrm{O}$ emissions in a permanent grassland under elevated atmospheric $\mathrm{CO}_{2}$ ?, Glob. Change Biol., 17, 3176-3186, 2011.

Roslev, P., Iversen, N., and Henriksen, K.: Oxidation and assimilation of atmospheric methane by soil methane oxidizers, Appl. Environ. Microb., 63, 874-880, 1997.

Rothe, A., Huber, C., Kreutzer, K., and Weis, W.: Deposition and soil leaching in stands of Norway spruce and European Beech: Results from the Hoglwald research in comparison with other European case studies, Plant Soil, 240, 33-45, 2002.

Schaufler, G., Kitzler, B., Schindlbacher, A., Skiba, U., Sutton, M. A., and Zechmeister-Boltenstern, S.: Greenhouse gas emissions from European soils under different land use: effects of soil moisture and temperature, Eur. J. Soil Sci., 61, 683-696, 2010.

Schindlbacher, A., Zechmeister-Boltenstern, S., and ButterbachBahl, K.: Effects of soil moisture and temperature on $\mathrm{NO}, \mathrm{NO}_{2}$, and $\mathrm{N}_{2} \mathrm{O}$ emissions from European forest soils, J. Geophys. Res., 109, D17302, doi:10.1029/2004JD004590, 2004.

Seiler, W., Conrad, R., and Scharffe, D.: Field Studies of Methane Emission from Termite Nests Into the Atmosphere and Measurements of Methane Uptake by Tropical Soils, J. Atmos. Chem., 1, 171-186, 1984.

Sitaula, B. K., Bakken, L. R., and Abrahamsen, G.: $\mathrm{CH}_{4}$ Uptake by Temperate Forest Soil - Effect of N Input and Soil Acidification, Soil Biol. Biochem., 27, 871-880, 1995.

Smith, K. A., Dobbie, K. E., Ball, B. C., Bakken, L. R., Sitaula, B. K., Hansen, S., Brumme, R., Borken, W., Christensen, S., Prieme, A., Fowler, D., Macdonald, J. A., Skiba, U., Klemedtsson, L., Kasimir-Klemedtsson, A., Degorska, A., and Orlanski, P.: Oxidation of atmospheric methane in Northern European soils, comparison with other ecosystems, and uncertainties in the global terrestrial sink, Glob. Change Biol., 6, 791-803, 2000.

Smith, K. A., Ball, T., Conen, F., Dobbie, K. E., Massheder, J., and Rey, A.: Exchange of greenhouse gases between soil and atmosphere: interactions of soil physical factors and biological processes, Eur. J. Soil Sci., 54, 779-791, 2003.

Solomon, S., Qin, D., Manning, M., Chen, Z., Marquis, M., Averyt, K., B., Tignor, M., and Miller, H., L.: The Physical Science Basis, in: Climate Change 2007, Cambridge Univ. Press, UK and New York, 129-235, 2007. 
Stehfest, E. and Bouwman, L.: $\mathrm{N}_{2} \mathrm{O}$ and $\mathrm{NO}$ emission from agricultural fields and soils under natural vegetation: summarizing available measurement data and modeling of global annual emissions, Nutr. Cycl. Agroecosys., 74, 207-228, 2006.

Steinkamp, R., Butterbach-Bahl, K., and Papen, H.: Methane oxidation by soils of an $\mathrm{N}$ limited and $\mathrm{N}$ fertilized spruce forest in the Black Forest, Germany, Soil Biol. Biochem., 33, 145-153, 2001.

Steudler, P. A., Bowden, R. D., Melillo, J. M., and Aber, J. D.: Influence of Nitrogen-Fertilization on Methane Uptake in Temperate Forest Soils, Nature, 341, 314-316, 1989.

Teh, Y. A. and Silver, W. L.: Effects of soil structure destruction on methane production and carbon partitioning between methanogenic pathways in tropical rain forest soils, J. Geophys. Res., 111, G01003, doi:10.1029/2005JG000020, 2006.

Teh, Y. A., Dubinsky, E. A., Silver, W. L., and Carlson, C. M.: Suppression of methanogenesis by dissimilatory Fe(III)-reducing bacteria in tropical rain forest soils: implications for ecosystem methane flux, Glob. Change Biol., 14, 413-422, 2008.

Topp, E. and Pattey, E.: Soils as sources and sinks for atmospheric methane, Can. J. Soil Sci., 77, 167-178, 1997.

van den Pol-van Dasselaar, A., van Beusichem, M. L., and Oenema, O.: Effects of soil moisture content and temperature on methane uptake by grasslands on sandy soils, Plant Soil, 204, 213-222, 1998.

Whalen, S. C. and Reeburgh, W. S.: Consumption of Atmospheric Methane by Tundra Soils, Nature, 346, 160-162, 1990.

Whalen, S. C. and Reeburgh, W. S.: Moisture and temperature sensitivity of $\mathrm{CH}_{4}$ oxidation in boreal soils, Soil Biol. Biochem., 28, 1271-1281, 1996.

Werner C., Kiese R., and Butterbach-Bahl, K.: $\mathrm{N}_{2} \mathrm{O}, \mathrm{CH}_{4}$ and $\mathrm{CO}_{2}$ flux measurements from tropical rainforest soils in western Kenya, J. Geophys. Res., 112, D03308, doi:10.1029/2006JD007388, 2007a.
Werner C., Butterbach-Bahl K., Haas E., Hickler T., and Kiese, R.: A global inventory of $\mathrm{N}_{2} \mathrm{O}$ emissions from tropical rainforest soils using a detailed biogeochemical model, Global Biogeochem. Cy., 21, GB3010, doi:10.1029/2006GB002909, 2007b.

Wolf, B., Zheng, X. H., Brueggemann, N., Chen, W. W., Dannenmann, M., Han, X. G., Sutton, M. A., Wu, H. H., Yao, Z. S., and Butterbach-Bahl, K.: Grazing-induced reduction of natural nitrous oxide release from continental steppe, Nature, 464, 881884, 2010.

Wu, X., Bruggemann, N., Gasche, R., Shen, Z. Y., Wolf, B., and Butterbach-Bahl, K.: Environmental controls over soilatmosphere exchange of $\mathrm{N}_{2} \mathrm{O}, \mathrm{NO}$, and $\mathrm{CO}_{2}$ in a temperate Norway spruce forest, Global Biogeochem. Cy., 24, GB2012, doi:10.1029/2009GB003616, 2010a.

Wu, X., Yao, Z., Bruggemann, N., Shen, Z. Y., Wolf, B., Dannenmann, M., Zheng, X., and Butterbach-Bahl, K.: Effects of soil moisture and temperature on $\mathrm{CO}_{2}$ and $\mathrm{CH}_{4}$ soil atmosphere exchange of various land use/cover types in a semi-arid grassland in Inner Mongolia, China, Soil Biol. Biochem., 42, 773-787, 2010b.

Yan, Y. P., Sha, L. Q., Cao, M., Zheng, Z., Tang, J. W., Wang, Y. H., Zhang, Y. P., Wang, R., Liu, G. R., Wang, Y. S., and Sun, Y.: Fluxes of $\mathrm{CH}_{4}$ and $\mathrm{N}_{2} \mathrm{O}$ from soil under a tropical seasonal rain forest in Xishuangbanna, Southwest China, J. Environ. Sci.China, 20, 207-215, 2008

Yashiro, Y., Kadir, W. R., Okuda, T., and Koizumi, H.: The effects of logging on soil greenhouse gas $\left(\mathrm{CO}_{2}, \mathrm{CH}_{4}, \mathrm{~N}_{2} \mathrm{O}\right)$ flux in a tropical rain forest, Peninsular Malaysia, Agr. Forest Meteorol., 148, 799-806, 2008.

Yavitt, J. B., Fahey, T. J., and Simmons, J. A.: Methane and CarbonDioxide Dynamics in A Northern Hardwood Ecosystem, Soil Sci. Soc. Am. J., 59, 796-804, 1995. 